\title{
Public References to Guilt and Presentation of Suspects and Accused Persons - Rule of Law in Bulgaria
}

\author{
HRISTINA VESELINOVA BOGIA
}

\begin{abstract}
The paper analyses the international rules on the rights of the accused in criminal proceedings related to the principles of publicity and the presumption of innocence. The rules of Directive (EU) 2016/343 of the European Parliament and of the Council in March 2016 on the strengthening of certain aspects of the presumption of innocence and of the right to be present at the trial in criminal proceedings and its implementation in the legislation in Bulgaria is referred. The author analyses the Media Strategy issued by the Supreme Judicial Council and a statement of the Commission for Personal Data Protection of the Republic of Bulgaria issued on an inquiry of Bulgaria's Prosecution Office.
\end{abstract}

Keywords: • presumption of innocence • Directive 2016/343 • Bulgaria • public $\bullet$ press release $\cdot$ data protection

CoRrespondence AdDREss: Hristina Veselinova Bogia, Law and Internet Foundation, 54 Balgarska Morava Str., Fl. 7, 1303 Sofia, Bulgaria, email: hristina.bogia@netlaw.bg.

https://doi.org/10.4335/978-961-6842-96-9.85-100

ISBN 978-961-6842-96-9 (pdf)

(C) 2020 Institute for Local Self-Government Maribor Available online at http://www.lex-localis.press. 
H. Veselinova Bogia: Public References to Guilt and Presentation of Suspects and Accused Persons - Rule of Law in Bulgaria

\section{$1 \quad$ Introduction}

It has been several years since the European Union (the EU) is active on ensuring that procedural rights in criminal trials are protected with certain guarantees in all Member States. Strengthening the presumption of innocence and the right to be present at the trial in criminal proceedings is on the agenda of the Union in relation with the principles of justice, security and freedom. Setting common standards in all EU Member States is a momentous step not only towards achieving judicial cooperation in civil and criminal matters in all Member States, but also in matters of police cooperation in the EU (Presidency Conclusions 1999 EC VI Tampere). An important milestone in this regard is the adoption of Directive (EU) 2016/343 of the European Parliament and of the Council in March 2016 on the strengthening of certain aspects of the presumption of innocence and of the right to be present at the trial in criminal proceedings (the Directive; Directive 2016/343).

The EU is a 'sui generis' legal system and since all Member States are obliged to bring their legislation in unison with the rules of EU legislation, in Bulgaria legislative changes are often undertaken in response of directives and regulations adopted by the EU. The fight against crime and the mutual recognition of judgments and other judicial decisions are important step towards achieving justice, security and freedom within the EU. After the adoption of the Lisbon Treaty (2009) the EU has been granted with competence in the area of criminal law and justice. According to article 83 of the Treaty, the European Parliament and the Council have the right to establish minimum rules concerning definition of criminal offences with directives. Directive 2016/343 is a step towards further developing the guarantees for the protection of fundamental human rights in criminal proceedings that are already laid down in several international legislative instruments.

Public references to guilt and presentation of suspects and accused persons in public are related to the principles of publicity of the trial and the work of the institutions on the one hand, and to the presumption of innocence, on the other. In Bulgaria, the obligation of the courts to publish their acts was established more than 20 years ago (Law on the Organization of the Judiciary 1994 Bulgaria), the presumption of innocence is also enshrined in the Bulgarian Criminal Procedure Code. Nevertheless, digitalization changed the way of carrying out the principle of publicity of the trial and the public delivering of judicial acts and brought challenges for the authorities to balance between the public interest and the individual's rights when they communicate their work to the public. 


\section{The right to a public trial and the presumption of innocence}

The right to a public trial and the presumption of innocence are enshrined in most international legislative instruments - the International Covenant on Civil and Political Rights (the ICCPR), the European Convention for the Protection of Human Rights and Fundamental Freedoms (the ECHR), the Charter of Fundamental Rights of the European Union etc. All of them are ratified and valid in Bulgaria.

\subsection{Right to a Public Trial}

The fair and public hearing within a reasonable time by an independent and impartial tribunal previously established by law is a widely recognized fundamental right (EU Charter of Fundamental Rights of the European Union 2012 Art. 47). In the context of democratic society it is indisputable that trials should be public, and individuals should have all the guarantees necessary for a defense (UN General Assembly Universal Declaration of Human Rights 1948 Art. 11.1). The press and the public can be excluded from all or just a part of a trial 'for reasons of morals, public order or national security in a democratic society' (International Covenant on Civil and Political Rights UN 1966/1976 Art. 14 .1; European Convention for the Protection of Human Rights and Fundamental Freedoms CE 1950 Art. 6.1). The same is applicable when the interest of the private live of the parties requires for some part of the proceeding to be held 'januis clausis'. It is up to the discretion of of the court to assess the extent of the exclusion.

Nevertheless, the judgments of criminal courts should be pronounced publicly. The exception for the public delivering of judgments is only in cases where juvenile persons are involved, thus their interests merit higher protection, or when the proceedings concern matrimonial disputes or the guardianship of children (International Covenant on Civil and Political Rights UN 1966/1976 Art. 14 .1). In the case of juvenile persons, the procedure takes account of their age. All means are set to promote rehabilitation and not just the punishment of juvenile offenders. The sensitive psychological state of juveniles allows the aims of the criminal proceedings to be reached with minimum intervention in their lives, that is also the foundation of the exemption of the principle of publicity. The legislation sets the basis for an assessment that should be made from the courts in each concrete case in order for the interests of the public, on one hand, and the individuals that are suspected or accused, on the other, to be protected. Nevertheless, public references to guilt and presentation of suspects and accused persons are not a subject matter of the abovementioned international documents. Public international law is in its nature abstract and aims to set a framework for the fundaments of the rights. Their further development is a matter of regional and national measures. In this relation, it is interesting to point out that there are many cases against Bulgaria when it comes to too restrictive measures on excluding the principle of publicity in court proceedings, but also on too wide publicity, e.g. public arrests, public statements, when it comes to activities in the course of the investigation that should be more confidential in order for the private lives of the accused 
to be protected (Raza v. Bulgaria, Nikolova and Vandova v. Bulgaria, Fazliyski v. Bulgaria).

\subsection{Presumption of innocence}

Public international law grants everyone who has been charged with a crime with the right to be presumed innocent until proved guilty according to the respective applicable law (International Covenant on Civil and Political Rights UN 1966/1976 Art. 14 .2, EU Charter of Fundamental Rights of the European Union 2012 Art. 48). Furthering, no one can be declared guilty of any penal offence on account of any act or omission which did not constitute a penal offence, under national or international law, at the time when it was committed (UN General Assembly Universal Declaration of Human Rights 1948 Art. 11.2).

Directive 2016/343 enshrines not only the presumption of innocence but also rules on the public references to guilt made in public statements by public authorities, measures regarding restricting actions from the authorities that could lead to presenting individuals as being guilty in public, rules on the burden of proof, the right to remain silent, the right to be present at the trial and the right to a re-trial. In general, all the fundamental rights and principles, already existing in other international legislative instruments. In the process of adoption of the Directive, it was proposed that the scope of application should be extended to legal persons also, it was discussed if it should be applicable to similar proceedings to those of a criminal nature, such that lead to comparable sanctions with punitive or deterrent nature (ECLAN 2016). The aim of such legislation is to ensure that Member States do not envisage any exemptions regarding the safeguards laid down in the Directive not only when it comes to the procedural rights of the accused but also in respect of the rules concerning public statements made from public authorities in an ongoing criminal proceedings (ibid.). In that case, if the Directive would apply also to organizations, they would have the right not to be presented as guilty or to be subject of public statements regarding criminal proceedings against them. The Committee proposed effective remedies to be taken to ameliorate breaches in an event of leak of information (ibid.).

After five trialogues held between January and October 2015, on 4 November 2015, the Committee of the Permanent Representatives of the Governments of the Member States to the European Union (the COREPER) approved the compromise text that was agreed with the European Parliament during the last trialogue and the Directive was signed on 9 March 2016, and published in the Official Journal on 11 March 2016 (OJ L 65). The deadline for the implementation ended on 1 April 2018 (ECLAN 2016). 


\subsection{Public Statements}

The texts of Article 4 and Article 5 of the Directive are ruling the obligation of Member States to ensure that as long as a suspect or an accused person has not been proved guilty according to law, public statements made by public authorities, and judicial decisions, other than those on guilt, do not refer to that person as being guilty. That means that Member States should implement rules for the public authorities, and they should be aware of the importance of respecting the presumption of innocence when issuing press releases or providing information to the media in any way. This is to be without prejudice to national law protecting the freedom of press and other media (Directive 2016/343 EU Recital 19). In Bulgaria there is no Media Law, the 'fourth estate' has but an ethical code that is not legally binding and nor obligatory. That is why it is important that the national authorities involved in criminal proceedings have strict rules on their public relations activities. Notwithstanding, the rules of the Directive regarding public statements of the authorities are not explicitly implemented in national legislation. Articles 4 and 5 of the Directive are laying down the rules for communication by public authorities involved in criminal proceedings in more detailed way than all abovementioned international legal instruments that regulate the principle of publicity of criminal trial.

That is an important guarantee for the right to access to information and the principles of publicity of criminal trial to be balanced in all Member States (Directive 2016/343 EU Recital 16). It is of great value that public awareness on criminal matters is possible. Nevertheless, when the statements of the authorities are based on suspicion or on elements of incriminating evidence, such as decisions on pre-trial detention, they should not refer to the suspect or accused person as being guilty (Directive 2016/343 EU Recital 16). The obligations of the authorities to verify that there are enough elements of incriminating evidence against the suspect or accused person is a guarantee for the safeguarding of the rights of individuals related to the presumption of innocence and the respect of their private lives. The rules of the Directive are not limiting or derogating from any of the rights and procedural safeguards that are already ensured under the Charter, the ECHR, the ICCPR, the UDHR or other relevant provisions of international law. The same is applicable when the rule of law of any Member State of the EU provides a higher level of protection (Directive 2016/343 EU Art. 13).

\subsection{Presenting Suspects or Accused Persons as Being Guilty}

Directive 2016/343 further stipulates the obligation to competent authorities to abstain from presenting suspects or accused persons as being guilty, in court or in public, using measures of physical restraint. Such measures are, according to the Directive - handcuffs, glass boxes, cages and leg irons. An exception can be made only when the use of such measures is required for case-specific reasons, related to security matters. For example to prevent suspects or accused persons from harming themselves or others or from damaging any property. Physical restraint measures are also possible when that is 
necessary for to the prevention of suspects or accused persons from absconding or from having contact with third persons, such as witnesses or victims (Directive 2016/343 EU Recital 20). Presenting suspects or accused persons in public or in court with prison clothes is also to be avoided (Directive 2016/343 EU Recital 21). Such measures leave the impression as if the individual is guilty before the court issues its final decision in a trial and it harms the right to be considered innocent until proved guilty according to the law.

In Bulgaria the transportation of accused persons is enshrined not in a law, but in a bylaw of the Minister of Interior (Instructions for the Organization and Order in the Implementation of Convoy Activities in the Ministry of Interior 2017). They do not include any rules regarding the right of the accused not to be presented as guilty in public, but rather are specifying the organization of the transportation, the competences and interaction between the authorities and the necessity of the physical restrain measures compared to the seriousness of the alleged crime in question. In 2018 when a mayor being charged with bribery was brought by the authorities to a hospital with handcuffs, both on the hands and legs (the Dessislava Ivancheva and Bilyana Petrova Case), a public discussion was opened if the rules on the transportation of accused persons should be subject to legislative changes. The focus was not the presumption of innocence in particular but the fact that the measures were not necessary. Up until the moment of the drafting of this paper no legislative changes followed.

For the purpose of comprehensives, it should be noted that Bulgarian legislation does not provide a legal definition for a 'suspect', nor is this procedural role regulate in any way. Individuals gain procedural rights in criminal proceedings only after the formal beginning of the proceedings (after being accused). The fact that the Directive's rules apply from the moment when an individual is suspected or accused (Directive 2016/343 EU Art. 2) is therefore useful in national context. Even though directives are not originally thought to be binding before their implementation in national laws of Member States, the doctrine of 'direct effect' developed by the European Court of Justice (the ECJ) allows individuals to claim damages that occur because of bad implementation or non-implementation of directives. In the case of Francovich v. Italy, the ECJ extended the principle of Van Gend en Loos to provide that Member States that failed to implement a directive could be liable to pay damages to individuals and companies who had been adversely affected by the unsuccessful attempt of the respective Member State to implement the rules of a directive. 


\section{Bulgarian legal framework}

The Bulgarian Constitution states in its Article 31 that anyone charged with a criminal offence must be brought before the judiciary within the time limit established by a law, no one may be compelled to plead guilty, nor may be convicted solely on the basis of the confession and accused individual should be presumed innocent until otherwise proven by an enforceable sentence. The rights of an accused party may not be restricted beyond what is necessary for the administration of justice. Individuals deprived of their liberty should be afforded conditions to exercise the fundamental rights that are not restricted by the effect of the sentence. On the other side, in Article 32 the private life of citizens is being announced inviolable. According to the Constitution everyone has the right to protection against any unlawful interference with their private or family life and against any encroachment on their honour, dignity, and reputation. It is not allowed for anyone to be followed, photographed, filmed, recorded, or to be a subjected to any other similar actions without their knowledge or despite their express disapproval, save in the cases provided for by the law (Constitution of the Republic of Bulgaria 1991 Art. 32.2).

In the chapter of the Criminal Procedure Code of Bulgaria dealing with the fundamental principles it is laid down that the court, the prosecutor and investigative bodies make their decisions according to their inner conviction, based on the objective, comprehensive and complete investigation of all circumstances relevant to the case (Criminal Procedure Code 2005 Art. 14). The rights of defense, the presumption of innocence and the publicity of the hearings are also enshrined and legally binding to all authorities within the criminal proceedings chain. National legislation does not refer any provisions regarding the publications on criminal proceedings, neither when the media is disseminating information about the proceeding's, nor when the competent authorities are spreading information through their websites and/or trough public interviews. Although in general, Bulgarian legislation is considered to be synchronized with the European democratic values, the ECHR dealt with 879 applications concerning Bulgaria in 2018, of which 841 were declared inadmissible or struck out. It delivered 29 judgments (concerning 38 applications), 27 of which found at least one violation of the European Convention on Human Rights (ECHR 2019).

\subsection{Implementation of the Directive}

Since directives leave Member States with a certain amount of leeway to the exact rules to be adopted, Directive 2016/343 explicitly states that Member States shall insert a reference to the Directive when implementing it in national legislation. Another possibility is the specific law to be accompanied by such reference on their official publication (Directive 2016/343 EU Art. 14.1). The information on the official EUR-Lex portal shows hat in Bulgaria the rules of Directive 2016/343 are implemented in several laws. 
In the concrete case, according to the official website of the EU, the section 'National Transposition' shows that the Directive is implemented in: Implementation of Penal Sanctions and Detention in Custody Act, Criminal Code, Act on the Liability for Damage Incurred by the State and the Municipalities (Title amended, SG No. 30/2006), Judiciary System Act, Obligations and Contracts Act, Criminal Procedure Code. Consultation with the Issues of the States Newspaper that promulgate the above-mentioned laws, shows that the legislative changes are fragmented, and it is not clear which of the legislative changes are corresponding to the rules of the Directive.

Although regulated, the publicity principles often are being violated in Bulgaria. The legislation is discontinuous and same is valid for the practices of prosecution, court and media. Often there is too much information that leads to shaping the public opinion on proceedings that are in a very early stage (i.e. Dessislava Ivancheva and Bilyana Petrova Case).Then, there are cases when a trial is of significant public interest, yet the public cannot get access to information (SG No. 63/4.08.2017 restricting the public delivering of judgments). And, last but not least, Bulgaria is holding one of the lowest places in the Ranking on press freedom of Reporters Without Borders (2019 World Press Freedom Index).

\subsection{Media Strategy of the Judiciary}

In 2016 the Supreme Judicial Council (the SJC) of the Republic of Bulgaria adopted a Media Strategy for the Judicial Authorities. The document lays down the grounds for interaction with the SJC and the judiciary with the media in order to promote the functions of the judiciary in the protection of the rights and legitimate interests of citizens, legal entities and the state. The Media Strategy synchronizes the existing rules among all courts and the prosecution bodies in Bulgaria. The Strategy includes rules and practices for communication with the media and aims at achieving uniform, clearly established and modern standards in media communication.

It includes the coordination of the activities and measures implemented by the judiciary. The implementation of the Media Strategy aims to ensure transparency in the work of the judiciary. The prosecution in Bulgaria is part of the judiciary, that is why the rules laid down in this document apply also to the investigation of criminal offences and proceedings in criminal trials. The strategy defines short-term goals, mid-term goals and long-term goals on transparency, building unified media policy of the judiciary, providing access to information etc. It emphasizes on the importance of achieving an effective model of interaction with the media, in order to ensure providing of adequate and objective information. The communication channels for the judiciary are the websites, Facebook Pages, livestreaming etc., but there are no rules on the content of the statements and the obligation of the authorities to avoid presenting suspected and accused persons as being guilty before a sentence is definitive. The Prosecution of the Republic of Bulgaria also has adopted rules on the communication with the media. The lack on concrete rules 
for the relation between public statements and the presumption of innocence is valid for them too. According to the rules, the Prosecution is responsible for continuously informing the society on its work with delivering information to the public in plain and clear way and with respect to the principles laid down in the Constitution and other Bulgarian laws.

The public relations activities of Bulgarian's Prosecution office were one of the topics on the Concept of the newly chosen chief prosecutor (Concept on the Strategic Management of the Prosecution of the Republic of Bulgaria 2019 Ivan Stoimenov Geshev). The vote for the Prosecutor General was one of the most discussed topics this year, not only because of the sole candidate, but also because of the lack of information of his work and the principles, stated in the strategy for the Prosecution, that includes rules on the public relations of the investigative body that could lead to unjustified public referral to guilt and political manipulations.

And, although, according to the abovementioned acts, publicity and transparency of the Bulgarian judiciary should be strengthened, in 2017 with legislative changes in the Criminal Procedure Code it was forbidden for the courts to publish court decisions on their website, unless it is confirmed from the Prosecution that the needed measures for bringing the penalty into force are being undertaken which was considered to be a step back from the main principles of publicity of criminal proceedings and transparency in the judiciary.

The international legislative instruments concerning fundamental principles of criminal proceedings and the EU legislation are developing same principles on publicity detailed and consistent, but the national legislation of Bulgaria is changing every couple of years - some changes include motives from directives, but they do not necessarily lead to the result foreseen. In the case of the publishing of court decisions and judgments in criminal matters, the reasoning was with the efforts of the prosecution to prevent the accused escaping justice. Completely illogical step to restrict publicity of the proceedings, when assessing that matter. The defendant has the obligation to inform the accused, it is slightly possible that the releasing of the judgment on the website of the court will lead to escaping justice. The Media Strategy shows that Bulgarian judiciary is aware of the importance of the public statements that authorities are making when it comes to criminal proceedings, but the policy makers do not have a uniform approach to that matter.

\subsection{The Commission for Personal Data Protection}

Apart from the Media Strategy and the Rules of the Prosecution, another important document that affects the matter of dissemination of information in criminal matters in Bulgaria, is a statement of the Bulgarian Commission for Personal Data Protection (the CPDP) issued on the request of the Bulgarian Prosecution on 26 June 2018, just a month after Regulation (EU) 2016/679 of the European Parliament and of the Council of 27 
April 2016 on the protection of natural persons with regard to the processing of personal data and on the free movement of such data, and repealing Directive 95/46/EC (General Data Protection Regulation) (the GDPR) came in force. As a data controller, the Prosecution has an obligation to respect all data protection laws, including GDPR, the matter of the inquiry is if data that enables the society to identify a certain person, such as first and family name, profession, workplace, family relationships, military rank etc. can be a subject of press releases. The concrete questions that the Bulgarian Prosecution asked CPDP were:

First, are the following actions a violation of the regulations in the field of personal data protection?

- Publication of personal data of participants in the pre-trial proceedings (accused persons, witnesses, etc.) on the prosecutor's office websites?

- Disposing of personal data to participants in pre-trial proceedings for journalistic purposes? If yes, in which cases? How does the handling of these cases relate to the presumption of innocence?

Second, if there are no obstacles regarding the transfer of personal data, is there any limit and, if yes, what are the boundaries that should be respected in order the rights of citizens to be protected? The Prosecution explicitly asked for specific answers to be provided from the CPDP.

The legal analysis in the statement of the CPDP underlines that the new EU legal framework on the protection of personal data, applicable from May 2018, includes two main legislative instruments - Directive (EU) 2016/680 of the European Parliament and of the Council of 27 April 2016 on the protection of natural persons with regard to the processing of personal data by competent authorities for the purposes of the prevention, investigation, detection or prosecution of criminal offences or the execution of criminal penalties, and on the free movement of such data, and repealing Council Framework Decision 2008/977/JHA (the Police Directive) and the GDPR. Meanwhile both are implemented in the national Data Protection Act. But that did not bring any clarity on the practical implementation of the legal framework. Not long ago the article that implements the GDPR rules on the processing of personal data for journalistic purposes and the journalistic exemption was declared unconstitutional. It is obvious that both policymakers and individuals in Bulgaria have issues on implementing the rules on data protection.

According to the statement of the CPDP, unlike the processing of personal data for the purpose of criminal proceedings (that falls under the scope of the Police Directive), the publication of press releases and the providing information to the media containing personal data of participants in pre-trial proceedings is processing for purposes other than the statutory role of the Prosecution in criminal proceedings and, in that matter, and thus is subject to the rules of GDPR. It was important for the practical implementation of both the Police Directive and the GDPR that this is clear, not only because of the overlapping of the scope of the acts, but also because of the legislative approach in Bulgaria. The 
Police Directive was implemented in the Data Protection Act, and although in a separate chapter - it is leading to a confusion to the processors of personal data if the rules are applicable to them, or not.

The legal basis for the Prosecution when disclosing data to the public is the performance of a task carried out in the public interest and in the exercise of official authority vested in the controller. The CPDP underlines that it should be taken account of the fact that the Prosecutor's office (and the authorities, part of the judicial system in general), in view of their statutory jurisdiction, do not process personal data for journalistic purposes. That is why they do not have to observe the special rules that are otherwise applicable to the media.

When personal data is being processed for journalistic purposes, the legitimate interest is the applicable legal basis (GDPR 2018 Art. 6.1.f ). In such cases the provision of Art. 85 of the GDPR, under which EU Member States have an obligation to reconcile the right to the protection of personal data with the right to freedom of expression and information, including processing for journalistic purposes is to apply. The CPDP emphasizes that those rights are of equal importance and therefore a proper, reasonable and proportionate balance should be sought in the exercise and protection of both. Since the legal basis in the national Data Protection Act of Bulgaria was declared unconstitutional, it is a matter of practical implementation and individual assessment to implement those rules in accordance with the GDPR in its integrity.

The Prosecution, as part of the Bulgarian judiciary, is also subject to public scrutiny. The public control over the activities of the Prosecution cannot be carried out without the publication of information about its work. Principles of publicity, transparency and accountability of the judiciary ensures public control over the bodies of the judiciary, in order to achieve justice, lawfulness and independence and to strengthen public confidence. In addition, in some cases the public interest may prevail over the interest of the individual, which results in the permissible and justified provision of personal data which should, however, be proportionate to the purpose. According to the statement of CPDP, public interest as a legal basis for lawful processing of personal data can be justified also in the means of the general prevention, laid down in the Criminal Code of the Republic of Bulgaria (Art. 36). In that case the dissemination of information on certain criminal offences can be seen as a tool for achieving prevention in the aspects of criminal justice, that results in the producing of an educative and deterring effect on the other members of society.

In its statement, the CPDP underlines also that when delivering public statements, the Prosecution, in its role of data controller, should assess for each separate case, whether the purpose for which the information is published on the Prosecution's website or in the media cannot be achieved by applying the approach outlined in Art. 64 of the Bulgarian Judiciary System Act, namely in a way that does not allow the identification of the 
individuals mentioned in them through pseudonymization (replacement of names with initials). The CPDP states that if it is impossible or inappropriate to publish the information pseudonymized, for reasons of achieving public awareness and public benefit, then the national identifier, address and names of individuals otherwise connected to the proceedings would be excessive. The Prosecution should also take specific measures to prevent the misidentification of another person in case of a coincidence of names and use additional features, including aliases, age, location, etc. The importance of the necessity of having access to information published by the Prosecution, is underlined by the national Data Authority also in accordance of Art. 204 of the Bulgarian Criminal Procedure Code, by virtue of it, pre-trial authorities should make extensive use of public assistance in detecting crimes and clarifying the circumstances of the case. Where justified and in proportion to the public danger of the perpetrator or the criminal act, the Prosecution may seek assistance from citizens through its website and/or the media, including through the publication of personal data - photographs, names, address or other facial data. Here an example can be given with the practice of the Bulgarian Ministry of Interior, which Sofia Directorate publishes pictures of individuals that are missing, with an unknown identity, or persons somehow connected to alleged crimes.

According to the CPDP, the authorities should widely use the assistance of the society in order to discover the criminal offence and to elucidate the circumstances of the case. The public interest of access to information could indeed outweigh the principles of protection of personal data. For instance, when the individual involved in criminal proceedings is holding a senior public office within the meaning of Art. 6 of the Counter-Corruption and Unlawfully Acquired Assets Forfeiture Act. The Constitutional Court of the Republic of Bulgaria already in 1996 has stated that 'the public authorities, as well as political figures and civil servants, may be subject to public criticism at a level higher than that of individuals. Initially, the level of personal data protection enjoyed by those persons is much lower in comparison to the level of protect enjoyed by the average citizen (Case 1/1996). Further, the Constitutional Court emphasizes, again, that authorities have an obligation to provide the public access to information on their activities.

In the inquiry of the Prosecution to the Data Protection Authority, special attention is paid to the connection between processing of personal data when publishing press releases and provision of information for journalistic purposes, on the one hand, and the presumption of innocence as a fundamental constitutional right of every citizen, on the other. According to Article 16 of the Bulgarian Criminal Procedure Code, the accused is presumed innocent until the contrary is established by a verdict. According to Article 20, court hearings are public, except in cases explicitly specified in the Code itself. Only the court can declare a person guilty or not guilty and the Prosecution in its procedural role as a party in the process, which raises and supports the charge of certain crimes should avoid disseminating information that could lead to assumptions that a person is guilty, before the delivery of a final verdict. Nevertheless, the CPDP states that it is in the public interest for the Prosecution to disseminate information and this does not violate the 
presumption of innocence, but merely provides information of the actions taken by the prosecution to detect and investigate criminal acts.

The CPDP underlines that it is important when assessing the proportionality of the publication of personal data by the Prosecution to pay attention to the distinction between the accused persons and the other participants in the pre-trial proceedings, such as witnesses, experts and others. In general, the statement is synchronized with the rules of Directive 2016/343 on the public statements and references to guilt of suspected and accused persons. Regarding the individuals involved in criminal proceedings, other than being accused or suspected, there is no overriding public interest and their personal data should not be made public. The national Data Protection Authority states that exemptions are possible in cases where senior public officials are involved or where the publication of the information protects the vital interests of the data subject, e.g. in the search for a missing person.

The Prosecution, in its role of data controller, should make an assessment based on objective criteria for how long it is justified to leave such information on its website, but there are no such criteria laid down in Bulgarian legislation. Each decision regarding the processing of personal data, should be taken on the basis of the specifics of the concrete case (Dimitrov, Ilieva, Makshturova 2018). When criminal proceedings are closed with a definitive act or the entry into force of a sentence acquitting a person, his or her right to privacy and protection of personal data outweighs the public interest in information, respectively, the information on the charge should be deleted as inaccurate or out of date, as stated from the CPDP. But that does not apply to conventional media. Even if the Prosecution office is obliged to delete data from its website, that is not the case when it comes to newspapers, magazines, news agencies. Every press release on the website of the Prosecution finds its place on the daily news, it is being indexed by Google, its being re-shared on Facebook, Twitter, Instagram. A year and a half after GDPR came into force, the complaints against media are growing. The rules of the GDPR are still unclear in Bulgaria, although implemented in national legislation.

To summarize:

- In Bulgaria the publication of personal data of accused persons in the pre-trial proceedings on the websites of the Prosecution, as well as the provision to the media for journalistic purposes, is lawful when there is a legal obligation or there is an overriding public interest;

- When it is impossible or inappropriate to publish the information in an anonymous or pseudonymized form, Bulgarian authorities should provide only minimum personal data to the public;

- The processing of personal data by the Prosecution for the prevention, investigation, detection or prosecution of crimes falls within the scope of the Police Directive and not the GDPR; 
H. Veselinova Bogia: Public References to Guilt and Presentation of Suspects and Accused Persons - Rule of Law in Bulgaria

- Personal data of witnesses, experts or other third parties, should not be published or otherwise disclosed, if there is no legal obligation to do so or overriding public interest;

- Personal data of individuals holding high public positions has lower protection in Bulgaria;

- The principles relating to processing of personal data (GDPR Art. 5) are to be followed.

\section{Conclusion}

The lack of detailed rules in the legislation of Bulgaria leads to issues in the practical implementation of the Directive when it comes to the objectivity of the information provided to the media. The rules on communication and public relations of the judiciary are a step towards unified and conscious approach in that matter, but 'de lege ferenda', legislative changes should implement the articles of the Directive, in order to avoid the authorities of making mistakes when disseminating that highly sensitive information. According to the Directive the term 'public statements made by public authorities' should be understood to be any statement which refers to a criminal offence and which emanates from an authority involved in the criminal proceedings concerning that criminal offence, such as judicial authorities, police and other law enforcement authorities, or from another public authority, such as ministers and other public officials, it being understood that this is without prejudice to national law regarding immunity (Directive 2016/343 EU Recital 16). The terms 'acts of the prosecution which aim to prove the guilt of the suspect or accused person', 'preliminary decisions of a procedural nature, which are taken by judicial or other competent authorities' and 'based on suspicion or incriminating evidence' should be implemented through legal definitions in Bulgarian national legislation in order mistakes to be avoided when disclosing information in the highly sensitive matters of criminal proceedings.

The obligation not to refer to suspects or accused persons as being guilty should not prevent public authorities from publicly disseminating information on the criminal proceedings, but only where this is strictly necessary for reasons relating to the criminal investigation, such as when video material is released and the public is asked to help in identifying the alleged perpetrator of the criminal offence, or to the public interest (Directive 2016/343 EU Recital 18). It should be possible to provide information to the public in order to prevent public order disturbance in cases of environmental crimes.

Each disclosure of information should be in accordance with principles of proportionality and minimisation. Several interests should be taken into account - of the individual, of the society, of the public authorities also. Not to create an impression that a person is guilty is highly sensitive and difficult. The obligation of the national legislator to ensure that appropriate measures are available in the event of a breach of the obligations laid down the Directive - not to refer to suspects or accused persons as being guilty, cannot be 
found in Bulgarian law. The same is valid for the appropriate measures that should be taken in order to ensure that suspects and accused persons are not presented as being guilty, in court or in public, using measures of physical restraint.

In the age of digital communications where the media is not only on the Internet through its websites, but also on Facebook, Twitter and Instagram, certain news can reach thousands of hundreds of people just in minutes, the responsibility of authorities involved in criminal proceedings to be mindful when the dissemination and communication of information on ongoing criminal proceedings is extremely high. The 'right to be forgotten' applicable to digital service providers is not a guarantee enough to the individual's personal life to be protected. It is just a response, reaction to an unlawful or inappropriate information dissemination. The damage already done to the reputation and good name of the accused cannot be erased. That is why the measures for prevention are the more appropriate respond in criminal justice matters.

\section{References:}

\section{International Legal Acts}

Directive (EU) 2016/343 of the European Parliament and of the Council of 9 March 2016 on the strengthening of certain aspects of the presumption of innocence and of the right to be present at the trial in criminal proceedings - https://eclan.eu/en/eu-legislatory/directive-eu-2016-343of-the-european-parliament-and-of-the-council-of-9-march-2016-on-the-strengthening-ofcertain-aspects-of-the-presumption-of-innocence-and-of-the-right-to-be-present-at-the-trialin-criminal-proceedings

UN General Assembly, International Covenant on Civil and Political Rights, 16 December 1966, United Nations, Treaty Series, vol. 999, p. 171, available at: https://www.refworld.org/docid/3ae6b3aa0.html

European Union, Charter of Fundamental Rights of the European Union, 26 October 2012, 2012/C 326/02, available at: https://www.refworld.org/docid/3ae6b3b70.html

Council of Europe, European Convention for the Protection of Human Rights and Fundamental Freedoms, as amended by Protocols Nos. 11 and 14, 4 November 1950, ETS 5, available at: https://www.refworld.org/docid/3ae6b3b04.html

Bulgarian Legal Acts and Documents

Media Strategy of the Judiciary of the Republic of Bulgaria http://www.vss.justice.bg/root/f/upload/12/Mediina_strategiq.pdf

Rules on Media Communication in the system of the Prosecution of the Republic of Bulgaria https://www.prb.bg/media/cms_page_media/6242/\%D0\%9F\%D1\%80\%D0\%B0\%D0\%B2\%D $0 \% \mathrm{~B} 8 \% \mathrm{D} 0 \% \mathrm{BB} \% \mathrm{D} 0 \% \mathrm{~B} 0 \% 20 \% \mathrm{D} 0 \% \mathrm{BC} \% \mathrm{D} 0 \% \mathrm{~B} 5 \% \mathrm{D} 0 \% \mathrm{~B} 4 \% \mathrm{D} 0 \% \mathrm{~B} 8 \% \mathrm{D} 0 \% \mathrm{~B} 9 \% \mathrm{D} 0 \% \mathrm{BD}$ $\% \mathrm{D} 0 \% \mathrm{~B} 0 \% 20 \% \mathrm{D} 0 \% \mathrm{BA} \% \mathrm{D} 0 \% \mathrm{BE} \% \mathrm{D} 0 \% \mathrm{BC} \% \mathrm{D} 1 \% 83 \% \mathrm{D} 0 \% \mathrm{BD} \% \mathrm{D} 0 \% \mathrm{~B} 8 \% \mathrm{D} 0 \% \mathrm{BA} \% \mathrm{D} 0$ $\%$ B0\%D1\%86\%D0\%B8\%D1\%8F.pdf

Statement of the Commission for Personal Data Protection for the publication of press-releases and giving information for journalistic purposes https://www.cpdp.bg/index.php?p=element_view\&aid=2116

Inquiry for declaring Article $25 \mathrm{~h}$ (regarding the processing of personal data for journalistic purposes) from the Bulgarian Data Protection Act unconstitutional, Case № 4/ 2019, available at: http://constcourt.bg/bg/Cases/Details/559 
H. Veselinova Bogia: Public References to Guilt and Presentation of Suspects and Accused Persons - Rule of Law in Bulgaria

Case № 1/ 1996, Bulgarian Constitutional Court, available at: http://www.constcourt.bg/bg/Cases/Details/225

Concept on the Strategic Management of the Prosecution of the Republic of Bulgaria 2019 Ivan Stoimenov Geshev, available at: http://www.vss.justice.bg/root/f/upload/24/i.g.koncepciya.pdf

Instructions for the Organization and Order in te Implementation of Convoy Activities in the Ministry of Home Affairs, 2017, available at: https://www.lex.bg/bg/laws/ldoc/2137176495

\section{Case Law and Decisions}

Andrea Francovich and Danila Bonifaci and others v Italian Republic, ECJ, 19 November 1991, Joined cases C-6/90 and C-9/90, ECLI identifier: ECLI:EU:C:1991:428, available at: https://eur-lex.europa.eu/legal-content/EN/TXT/?uri=CELEX\%3A61990CJ0006

Judgment of the Court of 5 February 1963, NV Algemene Transport- en Expeditie Onderneming van Gend \& Loos v Netherlands Inland Revenue Administration, Reference for a preliminary ruling: Tariefcommissie - Netherlands, Case 26-62 - https://eur-lex.europa.eu/legalcontent/EN/TXT/?uri=CELEX\%3A61962CJ0026

Case of Raza v. Bulgaria, Application no. 31465/08, Council of Europe: European Court of Human Rights, 11 February 2010, available at: https://www.refworld.org/cases,ECHR,4d429fe82.html

Case of Nikolova and Vandova v. Bulgaria, Application no. 20688/04, Council of Europe: European Court of Human Rights, 17 December 2013, available at: https://www.conjur.com.br/dl/europa-bulgaria-sigilo-processo.pdf

Fazliyski v. Bulgaria, Application no. 40908/05, Council of Europe: European Court of Human Rights 16 April 2013, available at: https://swarb.co.uk/fazliyski-v-bulgaria-echr-16-apr-2013/

European Council, Tampere, 15 and 16 October 1999, Presidency Conclusions http://www.europarl.europa.eu/summits/tam_en.htm\#c

Council Framework Decision 2009/299/JHA of 26 February 2009 amending Framework Decisions 2002/584/JHA, 2005/214/JHA, 2006/783/JHA, 2008/909/JHA and 2008/947/JHA, thereby enhancing the procedural rights of persons and fostering the application of the principle of mutual recognition to decisions rendered in the absence of the person concerned at the trial https://eur-lex.europa.eu/legal-content/EN/ALL/?uri=CELEX\%3A32009F0299

Other Resources

National transposition measures communicated by the Member States concerning: Directive (EU) 2016/343 of the European Parliament and of the Council of 9 March 2016 on the strengthening of certain aspects of the presumption of innocence and of the right to be present at the trial in criminal proceedings

https://eur-lex.europa.eu/legalcontent/EN/NIM/?uri=CELEX:32016L0343

Press Country Profile of the ECHR - https://www.echr.coe.int/Documents/CP_Bulgaria_ENG.pdf Political repression and violation of the human rights of two women politicians in Bulgaria http://www.europarl.europa.eu/doceo/document/E-8-2018-006006_EN.html

2019 World Press Freedom Index, available at: https://rsf.org/en/bulgaria

Dimitrov G., Ilieva D., Makshutova R., (2018) What data protection rights do employees have in 2018. The right to personal life, the GDPR and the balance of interests - Privacy in Germany, Ausgabe 01/2019, available at: https://www.pingdigital.de/ce/what-data-protection-rights-doemployees-have-in-2018/detail.html 